\title{
Effects of physical exercise on beta cells of the pancreas: a systematic review
}

\author{
Edson Meneses da Silva Filho', Jéssica Andrade de Albuquerque ${ }^{2}$, Roberta de Oliveira Cacho³, \\ Rodrigo Pegado de Abreu Freitas ${ }^{3}$
}

\begin{abstract}
Background: Diabetes mellitus is a chronic disease that is rising in many parts of the world causing damage to functionality, quality of life and public health system. Objective: Verify the effects of physical exercise on beta cells of the pancreas in diabetic subjects. Methods: The database Cochrane Library via Wiley - CENTRAL, Pubmed, LILACS, SCIELO, Web of Science, Scopus, CINAHL were used to search the articles. The descriptors and synonyms of this topic were used in the search strategy. Controlled randomized clinical trials and quasi-randomized studies, which included in their samples diabetic humans undergone any type of physical exercise were included. The Cochrane collaboration bias risk tool was used to assess the risk of bias. Results: A total of 3.133 articles were initially identified and after reading the titles/abstracts and the full text 6 articles were selected for the qualitative evaluation. Most of the studies showed positive results of physical exercise on pancreatic beta cells, insulin secretion, insulin resistance and insulin sensitivity. The main limitations were the number of studies, few, and their methodological qualities. Conclusions: Physical exercises have beneficial effects on pancreatic beta cells, insulin resistance and insulin sensitivity; however better studies designs, with fewer biases and larger samples are needed so that the results presented do not be overestimated. This review is recorded in the Prospective Register of Systematic Reviews with registration number 42017054213.
\end{abstract}

Keywords: Insulin-Secreting Cells; Diabetes Mellitus; Exercise.

\section{INTRODUCTION}

Diabetes mellitus is a chronic disease that has presented alarming data on its incidence and prevalence. Some data on the prevalence of self-reported diabetes in Brazil presented an estimated 9 million people in the country, about 3.5 million of them aged 65 years or over ${ }^{(1)}$. According to the International Diabetes Federation there is a projection that 592 million people will suffer from diabetes in $2030^{(2)}$. Factors such as deficits in insulin and glucagon secretion influence the development of diabetes ${ }^{(3)}$, although other factors such as overweight and increased abdominal fat may also influence the development of this pathology ${ }^{(4)}$. It is noteworthy that beta cells, located in the pancreas, produce the hormone insulin, exerting a direct influence on glycemic control and when damaged directly affect the production of this hormone $e^{(5)}$. In an attempt to find ways to control insulin action, a study was conducted with healthy subjects, indicating that there was release of humoral mediators after physical exercise (PE), resulting in the prevention of the proinflammatory action of cytokines, which destroy the beta cells of the pancreas, demonstrating that the practice of physical activities reduces the deterioration of the beta cells of the pancreas, generating greater production of insulin in healthy people ${ }^{(6)}$. Despite the knowledge of some benefits generated by PE in healthy subjects, other forms of treatment have also been used to control glycemia, such as the ingestion of high doses of vitamin $D^{(7)}$, the use of medication ${ }^{(8,9)}$ and sleep control ${ }^{(10)}$. Although there is an understanding of the effects of the practice of PE on various physiological functions related to glycemic control in various populations, information on the impact of aerobic and anaerobic PE on pancreatic beta cells in the population of patients with diabetes is still unknown. Considering the assumptions presented, this work aims to perform a systematic review about the effects of aerobic and anaerobic exercises on pancreatic beta cells in diabetic patients compared to any active control group or with non-PE. 


\section{METHOD}

This review followed the recommendations of the Preferred Reporting Itens for Systematic Reviews and Meta-Analyses (PRISMA) $)^{(11)}$ and is registered in the Prospective Register of Systematic Reviews - PROSPERO with number 42017054213. The last search was made on August 6, 2017. Primary, controlled and randomized clinical trials and quasi-randomized studies were included, which included patients with type 1 and/or type 2 diabetes undergoing aerobic and/or anaerobic exercise for at least 30 minutes of duration, using pancreatic beta cells as the primary endpoint and glucose tolerance, insulin secretion/concentration, insulin resistance and insulin sensitivity as secondary endpoints. There was no restriction in relation to the period of follow-up for the eligibility of the included studies, nor any other limitation in relation to the languages, year or situation of the publication during the searches of the studies in the databases. The Cochrane Library via Wiley - CENTRAL, Pubmed, LILACS, SCIELO, Web of Science, Scopus, CINAHL databases were used for the search of the articles because they contain a large part of the periodicals related to the subject under study. The clinical trial registry (clincaltrials.org) was also used as a search source in an attempt to map studies that are still ongoing. The entire search strategy was done by two researchers independently using the descriptors for the simple searches and their respective synonyms for the sensitized search. After the search, the titles of the articles were read in order to exclude those who clearly did not approach the proposed theme. In case of doubts the articles were stored so that the abstracts were read and if the doubt persisted they were read integrally. The selection process of the studies was done by two researchers independently and at the consensus meeting it was decided which of the articles would be part of the review. If there was a disagreement a third researcher was consulted. After the selection of the articles, the data were collected through a form created by the researchers in order to obtain all the relevant data of the included studies. Data were collected regarding the objectives, sample characteristics, interventions, outcomes and main results of each study. The Cochrane Collaboration tool was used to assess the risk of bias in the included studies. The items of the included studies were analyzed and judged judiciously, according to the handbook chochrane ${ }^{(12)}$. The evaluation process was done by two researchers independently and if there was disagreement a third researcher was consulted.

\section{RESULTS}

A total of 3,133 articles were initially identified. After reading the titles/abstracts, 3,126 papers were excluded because they did not meet the inclusion criteria, with a total of 13 articles remaining eligible. Finally, after the full reading, 6 articles were selected for the qualitative evaluation, as represented in figure 1 . The articles presented

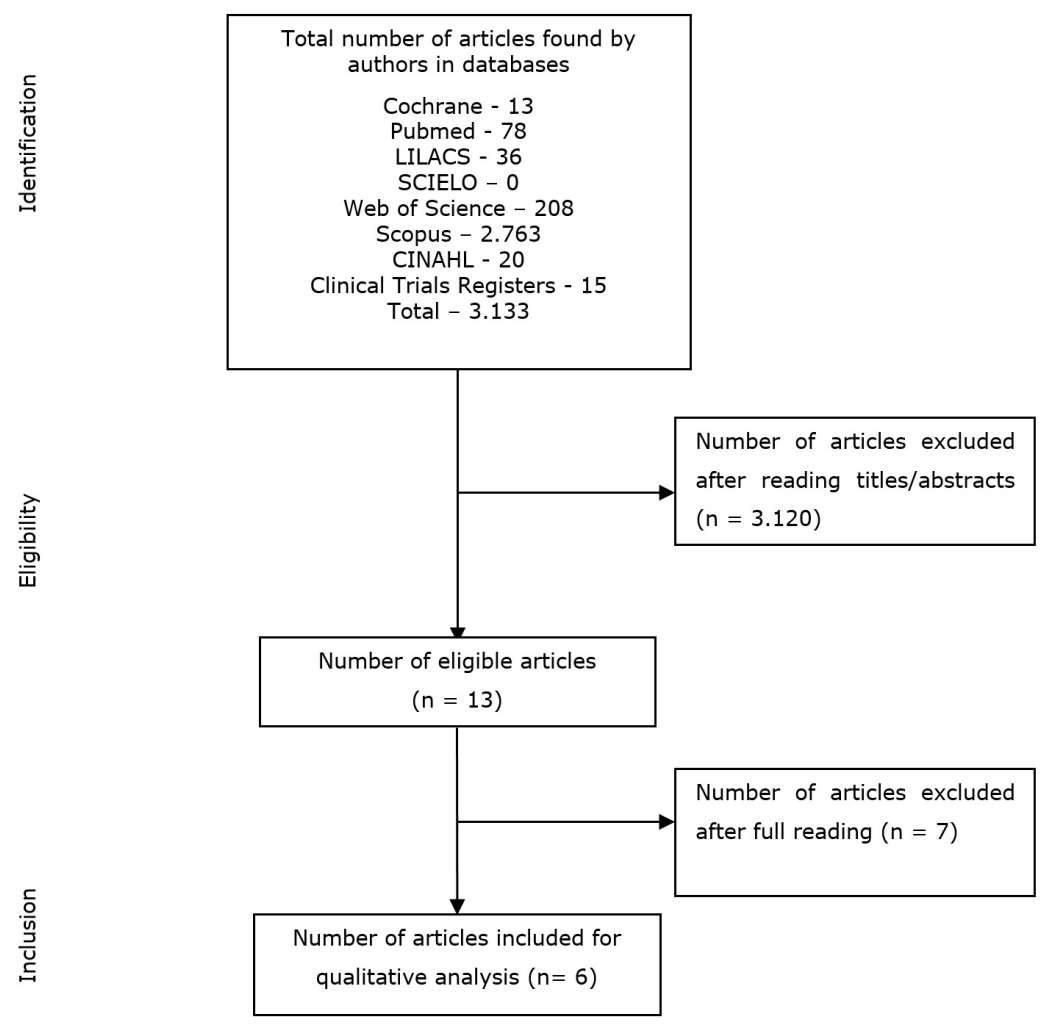

Figure 1. Flowchart of the studies selection. 
a total of 194 type 2 diabetics in their samples and 31 controls (non-diabetic), but the number of subjects analyzed in the outcomes varied between the studies, for example beta cell function $(n=225)$, insulin secretion $(n=74)$, insulin concentration $(n=54)$, insulin resistance $(n=170)$, insulin sensitivity ( $n=225)$ and plasma glucose concentration $(n=23)$. Table 1 shows the characteristics of the included studies. Considering the methodological quality of the 6 articles included in this review it is emphasized that all presented high risk of bias, as shown in figure 2 .

Table 1. Characteristics of the included studies.

\begin{tabular}{|c|c|c|c|c|}
\hline References & Objective & Sample characteristics & Intervention/Outcome & Main results \\
\hline 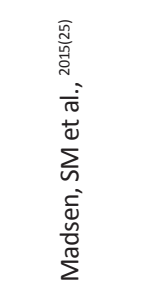 & $\begin{array}{l}\text { To investigate glycemic } \\
\text { control, pancreatic } \\
\text { function and total fat } \\
\text { mass before and after } 8 \\
\text { weeks of low intensity } \\
\text { interval training in a } \\
\text { cycloergometer in type } \\
2 \text { diabetic patients and } \\
\text { healthy subjects. }\end{array}$ & $\begin{array}{l}\text { The sample consisted } \\
\text { of } 23 \text { subjects divided } \\
\text { into } 2 \text { groups: Group } \\
\text { with } 10 \text { sedentary type } 2 \\
\text { diabetics, mean age: } 52 \\
\pm 2 \text { years; Control group } \\
\text { with } 13 \text { healthy subjects, } \\
\text { mean age: } 52 \pm 2 \text { years. }\end{array}$ & $\begin{array}{l}\text { subjects exercised } 3 \text { times / week } \\
\text { with high-intensity interval training } \\
\text { for } 8 \text { weeks in a cycloergometer. } \\
\text { Outcomes: oral test of glucose } \\
\text { tolerance (to assess beta cell } \\
\text { function and insulin resistance), } \\
\text { plasma glucose and insulin } \\
\text { sensitivity / concentration. }\end{array}$ & $\begin{array}{l}\text { In the diabetic group, glycemic control, glucose } \\
\text { continuity and glycated hemoglobin were } \\
\text { significantly improved, as well as insulin resistance, } \\
\text { beta cell function and insulin sensitivity. Insulin } \\
\text { secretion remained unchanged. }\end{array}$ \\
\hline 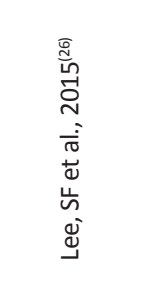 & $\begin{array}{l}\text { To investigate the } \\
\text { effectiveness of two } \\
\text { moderate-intensity } \\
\text { exercise programs on } \\
\text { glucose metabolism } \\
\text { and pancreatic beta cell } \\
\text { function in patients with } \\
\text { type } 2 \text { diabetes. }\end{array}$ & $\begin{array}{l}\text { The sample consisted } \\
\text { of } 120 \text { type } 2 \text { diabetic } \\
\text { patients ( } 62 \text { female) } \\
\text { with mean age: } \\
55.54 \pm 9.09 \text { years and } \\
\text { diagnosed in } 14 \pm 5.24 \text { years } \\
\text { before. }\end{array}$ & $\begin{array}{l}\text { The patients were randomized into } \\
3 \text { groups: aerobic exercise group, } \\
\text { millions of accumulated steps group } \\
\text { or control group each with } 40 \\
\text { people. All performed exercises for } \\
12 \text { weeks / time per day, } 5 \text { days per } \\
\text { week, lasting } 30 \text { minutes. Outcomes: } \\
\text { glucose metabolism and pancreatic } \\
\text { cell function. }\end{array}$ & $\begin{array}{l}\text { Regardless of the type of intervention there } \\
\text { are potential benefits to glucose metabolism } \\
\text { and pancreatic cell function of type } 2 \text { diabetics. } \\
\text { The millions of accumulated steps group had } \\
\text { better results on glucose metabolism and beta cell } \\
\text { function compared to the aerobic exercise group. }\end{array}$ \\
\hline 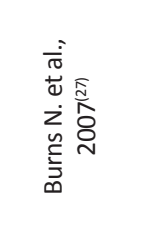 & $\begin{array}{l}\text { To examine the effects } \\
\text { of a 3-month aerobic } \\
\text { exercise program on } \\
\text { young insulin resistant } \\
\text { obese patients with and } \\
\text { without type } 2 \text { diabetes. }\end{array}$ & $\begin{array}{l}\text { The sample consisted } \\
\text { of } 31 \text { subjects: } 13 \text { were } \\
\text { diabetic type } 2 \text { with } \\
\text { mean age of } 25.8 \text { years } \\
\text { and } 18 \text { were non-diabetic } \\
\text { with mean age of } \\
23.7 \text { years. }\end{array}$ & $\begin{array}{l}\text { The entire sample practiced } 1 \text { hour } \\
\text { of exercise daily, } 4 \text { times a week } \\
\text { for } 12 \text { weeks. Outcome: Insulin level, } \\
\text { insulin sensitivity and secretion and } \\
\text { beta cell function. }\end{array}$ & $\begin{array}{l}\text { Any groups presented significant results on the } \\
\text { outcomes analyzed after the aerobic exercise } \\
\text { intervention. }\end{array}$ \\
\hline 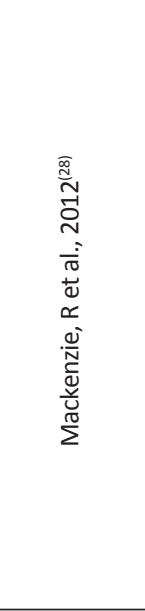 & $\begin{array}{l}\text { To examine the } \\
\text { effectiveness of } \\
\text { intermittent exercise } \\
\text { with and without hypoxia } \\
\text { in type } 2 \text { diabetics in } \\
\text { acute and moderate } \\
\text { terms of glucose kinetics } \\
\text { and insulin sensitivity. }\end{array}$ & $\begin{array}{l}\text { The sample consisted } \\
\text { of } 8 \text { sedentary men } \\
\text { diagnosed not more } \\
\text { than } 5 \text { years with type } \\
2 \text { diabetes. Mean age: } \\
58.7( \pm 2.2) \text {. }\end{array}$ & $\begin{array}{l}\text { The first visit allowed the collection } \\
\text { of preliminary data and the } \\
\text { achievement of lactate threshold } \\
\text { values under normal conditions } \\
\text { of hypoxia (without hypoxia). The } \\
\text { subjects practiced exercises in } 3 \\
\text { conditions of hypoxia separated by at } \\
\text { least } 7 \text { days for each type of exercise } \\
\text { done. } \\
\text { After each exercise session (day } 1 \text { ) } \\
\text { the participants returned to the } \\
\text { laboratory after } 24 \mathrm{~h} \text { (day } 2 \text { ) and } \\
48 \mathrm{~h} \text { (day } 3 \text { ) for the measurement of } \\
\text { glucose kinetics and glycemic control. } \\
\text { Outcomes: Insulin sensitivity, insulin } \\
\text { resistance, and beta cell function. }\end{array}$ & $\begin{array}{l}\text { Sixty minutes of continuous exercise at } 90 \% \text { of } \\
\text { the lactate threshold in hypoxia provided the best } \\
\text { results in the control of glucose on type } 2 \text { diabetics } \\
\text { in acute and moderate terms. Intermittent exercise } \\
\text { increased beta cell function, stimulated glucose } \\
\text { elimination, and improved insulin resistance after } \\
\text { exercise combined with hypoxia } 5: 5 \text { ( } 5 \text { minutes of } \\
\text { exercise and } 5 \text { minutes of rest). } \\
\text { The blood glucose concentration decreased } \\
\text { and its sensitivity increased in similar degrees } \\
\text { during the } 2 \text { forms of exercise: exercise for } \\
5 \text { minutes at } 120 \% \text { of the lactate threshold, } \\
\text { separated by } 5 \text { minutes of passive recovery } \\
\text { totaling } 60 \text { minutes and exercise in Hypoxia } 5: 5 \\
\text { (5 minutes of exercise and } 5 \text { minutes of rest). } \\
\text { Hypoxia } 60 \text { ( } 60 \text { minutes of continuous exercise at } \\
90 \% \text { of the lactate threshold in hypoxia) improved } \\
\text { insulin resistance } 24 \text { hours after exercise. }\end{array}$ \\
\hline 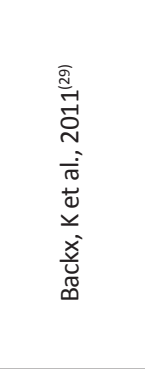 & $\begin{array}{l}\text { To examine the } \\
\text { effectiveness of a } \\
\text { 12-week standard care } \\
\text { program or a supervised } \\
\text { exercise program on } \\
\text { glycemic control, beta } \\
\text { cell response, insulin } \\
\text { resistance and lipid } \\
\text { profile in patients } \\
\text { newly diagnosed with } \\
\text { type } 2 \text { diabetes. }\end{array}$ & $\begin{array}{l}\text { The sample consisted } \\
\text { of } 19 \text { patients with type } \\
2 \text { diabetes ( } 15 \text { males), } \\
\text { median age of } 59.6 \text { years. }\end{array}$ & $\begin{array}{l}\text { The standard program consisted of } \\
\text { guidelines for moderate and high } \\
\text { intensities exercises for } 30 \text { minutes, } \\
5 \text { times a week; the supervised } \\
\text { exercise program consisted of } 3 \\
\text { exercises with } 60 \text {-minute support and } \\
2 \text { unsupported exercises per week for } \\
12 \text { weeks. } \\
\text { Outcomes: Acute insulin response, } \\
\text { beta cell response and Insulin } \\
\text { secretion / resistance. }\end{array}$ & $\begin{array}{l}\text { No difference between groups in all outcomes. No } \\
\text { significant changes in beta cell response or insulin } \\
\text { resistance were observed after the standard care } \\
\text { program, however, after the supervised exercise } \\
\text { program, beta cell rapid response and insulin } \\
\text { resistance decreased significantly. A significant } \\
\text { increase in the acute insulin response to glucose } \\
\text { was observed after the supervised exercise } \\
\text { program. }\end{array}$ \\
\hline
\end{tabular}


Table 1. Characteristics of the included studies.

\begin{tabular}{|c|c|c|c|c|}
\hline References & Objective & Sample characteristics & Intervention/Outcome & Main results \\
\hline 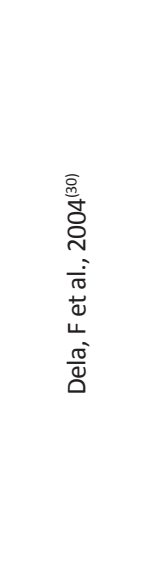 & $\begin{array}{l}\text { To analyze whether } \\
\text { physical training } \\
\text { generates changes in } \\
\text { pancreatic beta cell } \\
\text { function in diabetic } \\
\text { patients classified as low } \\
\text { or moderate capacity of } \\
\text { beta cell secretion. }\end{array}$ & $\begin{array}{l}24 \text { type } 2 \text { diabetic } \\
\text { men were randomized } \\
\text { into groups according } \\
\text { to their secretion: } \\
\text { group with moderate } \\
\text { beta cell secretion } \\
\text { capacity ( } 9 \text { performed } \\
\text { physical training; mean } \\
\text { age: } 54 \pm 2 \text { years) or } \\
\text { ( } 7 \text { sedentary patients } \\
\text { with mean age: } 53 \pm 4 \\
\text { years); Low secretory } \\
\text { capacity of beta cells } \\
\text { (5 performed physical } \\
\text { training, mean age: } 52 \pm \\
4) \text { or }(3 \text { sedentary, mean } \\
\text { age } 47 \pm 1 \text { ). }\end{array}$ & $\begin{array}{l}\text { Patients were classified as moderate } \\
\text { and low secretors according to the } \\
\text { C-peptidic response to the glucagon } \\
\text { test. } \\
\text { The training (cycle ergometer) were } \\
30-40 \text { min/day, including } 20 \text { min of } \\
75 \% \text { of max oxygen consumption } \\
\text { for } 5 \text { days/week or were in without } \\
\text { physical activity (sedentary) for } 12 \\
\text { weeks. } \\
\text { Outcomes: insulin sensitivity / } \\
\text { secretion and beta cell function } \\
\text { (before intervention and after } 3 \\
\text { months). }\end{array}$ & $\begin{array}{l}\text { No change in beta cell response was observed after } \\
\text { physical training in the low secretion group. On } \\
\text { the other hand, moderate secretors significantly } \\
\text { increased beta cell function after training. } \\
\text { Insulin sensitivity / secretion was not altered by } \\
\text { training in any group. } \\
\text { During the } 3 \text { months of sedentary lifestyle in both } \\
\text { groups, insulin and C-peptide were not modified. }\end{array}$ \\
\hline
\end{tabular}

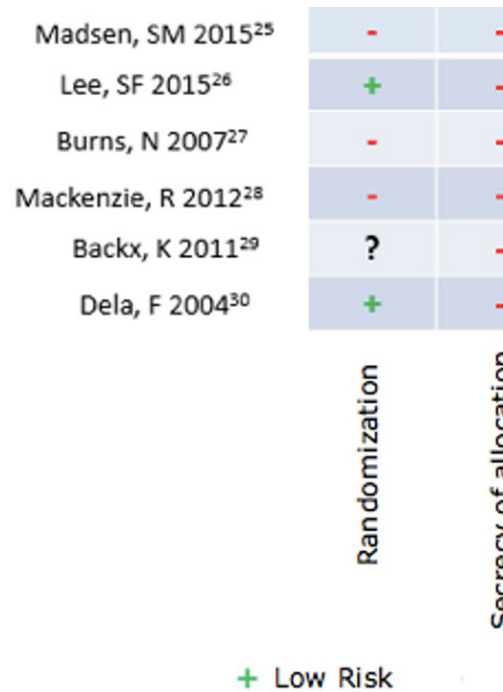

Figure 2. Bias risk analysis of the included studies.

\section{DISCUSSION}

This is the first systematic review of studies that analyzed the effects of PE using as primary endpoint the beta cells of the pancreas of diabetic patients. In addition, it is important to mention that there are few studies that used beta cells of the pancreas in this population as primary endpoint. The beta cells, located in the pancreas, are important producers of insulin and they can do this complex work at any moment, through innumerable physiological and environmental stimuli. When insulin sensitivity decreases, producer cells may lose their function ${ }^{(13)}$ and according to Kahn et al.(14), pioneers on the field, there is a hyperbolic relationship between the action of beta cells and insulin sensitivity, i.e., there is a homeostasis while beta cells can increase or decrease their production, according to changes in insulin sensitivity, so it is essential the maintenance of its function. The diabetic patients involved in the studies of this review presented beneficial responses on beta cells after PE. One possible explanation would be because of the release of humoral mediators ${ }^{(6)}$ and increased secretion of the glucagon-like peptide-1 hormone ${ }^{(15)}$. These elements generate protective effects on the beta cells, for example, by reducing the death of these cells and stimulating their proliferation. In addition to $\mathrm{PE}$, there are other variables not analyzed by the studies included in this review that may influence beta cell function, including sleep duration ${ }^{(16)}$ and compounds present in the diet, such as Kaempferol(17). Regarding the results that there are no benefits after the practice of PE on beta cells, these can be justified by the limited amount of PE taxes and sedentary behaviors of the sample ${ }^{(18)}$. Another factor would be the body weight of subjects, that 
may have had a negative influence on glycated hemoglobin, which is a parameter used to verify glycemic metabolism after the practice of PE (19). As glycated hemoglobin, there are other means to verify some outcome related to glucose metabolism, for example, the gold standard for measuring insulin resistance is the euglycemic-hyperglycemic clamping ${ }^{(20)}$, although there are also other validated forms of measurement such as fasting glycemia(21). Considering the improvements found by some studies regarding insulin resistance, this can be justified because of the increase in lean mass, decrease of total and visceral fat in the PE practitioners, thus contributing to decrease the insulin resistance ${ }^{(22)}$.

Regarding insulin secretion, some studies of this review have demonstrated that there is no significant influence of PE on diabetic subjects. Contradictory results were observed by other authors on the grounds that the types of PE, rest time, load and frequency used may have influenced the difference in response between the studies ${ }^{(23,24)}$.

The investigated studies presented conflicting results in relation to the outcomes analyzed, and may have occurred due to the different methods used, for example, study designs, inclusion and exclusion criteria, sample size and different $P E$ interventions. This review presented as a limitation the low number of studies. It should be noted that although the majority of the articles presented positive results regarding the practice of PE on pancreatic beta cells, insulin resistance and insulin sensitivity, caution should be exercised in the results since, according to table of risk of bias, all articles presented in this review had a high risk of bias.

\section{CONCLUSION}

Physical exercises have beneficial effects on pancreatic beta cells, insulin resistance and insulin sensitivity, but better study designs are required, with less risk of bias and with larger samples so that the results presented are not overestimated.

\section{AUTHORS' CONTRIBUTIONS}

All authors contributed to the design of the study, reviewing important intellectual contents, and analyzing and interpreting the data. All of them are responsible for the aspects of the work, ensuring the accuracy and integrity of the information contained therein. In addition, they have critically reviewed and approved the final version for publication.

\section{CONFLICTS OF INTEREST}

The authors declare that there was no conflict of interests.

\section{AUTHOR DETAILS}

2 Departamento de Psicologia Social, Universidade Federal da Paraíba - UFPB - João Pessoa, PB, Brasil. ${ }^{3}$ Physiotherapy Department, Universidade Federal do Rio Grande do Norte - UFRN - Santa Cruz, RN, Brasil.

\section{REFERENCES}

1. Iser B, Stopa S, Chueiri P, Szwarcwald C, Malta D, Monteiro H, et al. Prevalência de diabetes autorreferido no Brasil: resultados da Pesquisa Nacional de Saúde 2013. Epidemiol. Serv. Saúde. 2015;24(2):305-314.
2. International Diabetes Federation [Internet]. [cited 2017 Aug 4]. Available from: http://www.idf.org.

3. Unger RH. Glucagon physiology and pathophysiology. New Engl Journal Med. 1971;19; 285(8):443-449.

4. Vasques CJ, Pereira PF, Gomide RM, Batista MC, Campos MT, Sant'ana $\mathrm{LF}$, et al. Influência do excesso de peso corporal e da adiposidade central na glicemia e no perfil lipídico de pacientes portadores de diabetes mellitus tipo 2. Arq. Brás. Endocrinol. Metab. 2007;51(9):1516-1521.

5. Solomon TP, Malin SK, Karstoft K, Kashyap SR, Haus JM, Kirwan JP. Pancreatic $\beta$-cell function is a stronger predictorof changes in glycemic control after an aerobic exercise intervention than insulin sensitivity. Journal Clin Endocrinol Metab. 2013;98(10):4176-86.

6. Christensen CS, Lundh M, Dahllöf MS, Haase TN, Velasquez JM, Laye MJ, et al. Skeletal muscle to pancreatic cell cross-talk: the effect of humoral mediators liberated by muscle contraction and acute exercise on cell apoptosis. Journal Clin Endocrinol Metab. 2015;100(10):1289-1298.

7. Wagner H, Alvarsson M, Mannheimer B, Degerblad M, Östenson CG. No effect of high-dose vitamin d treatment on $\beta$-cell function, insulin sensitivity, or glucose homeostasis in subjects with abnormal glucose tolerance: a randomized clinical trial. Diabetes Care. 2016;39(3):345-52.

8. Merovci A, Abdul-Ghani M, Mari A, Solis-Herrera C, Xiong J, Daniele $G$, et al. Effect of dapagliflozin with and without acipimox on insulin sensitivity and insulin secretion in T2DM males. J Clin Endocrinol Metab. 2016;101(3):1249-1256.

9. Mari A, Rosenstock J, Ma X, Li YG, Jackson JA. Optimized human regular U-500 insulin treatment improves $\beta$-cell function in severely insulinresistant patients with long-standing type 2 diabetes and high insulin requirements. Endocr Pract. 2015;21(12):1344-1352.

10. Zhu Y, Li AM, Au CT, Kong AP, Zhang J, Wong CK, et al. Association between sleep architecture and glucose tolerance in children and adolescents. J Diabetes. 2015;7(1):10-15.

11. Moher D, Liberati A, Tetzlaff J, Altman DG; PRISMA Group. Preferred reporting items for systematic reviews and meta-analyses: the PRISMA statement. Ann Intern Med. 2009;151(4):264-269.

12. Higgins JPT, Altman DG. Assessing risk of bias in included studies. In: Higgins JPT, Green S, eds. Cochrane handbook for systematic reviews of interventions. Wiley. 2008:187-241.

13. Ferrannini E, Mari A. Beta cell function and its relation to insulin action in humans: a critical appraisal. Diabetologia. 2004;47:943-956.

14. Kahn SE, Prigeon RL, McCulloch DK. Quantification of the relationship between insulin sensitivity and beta-cell function in human subjects. Evidence for a hyperbolic function. Diabetes. 1993;42:1663-1672.

15. Campbell RK. Fate of the beta-cell in the pathophysiology of type 2 diabetes. J Am Pharm Assoc. 2009;49(1):10-15.

16. Rutters F, Besson $\mathrm{H}$, Walker M, Mari A, Konrad T, Nilsson PM, et al. The Association Between Sleep Duration, Insulin Sensitivity, and b-Cell Function: The EGIR-RISC Study. J Clin Endocrinol Metab. 2016;101(9):327280.

17. Alkhalidy H, Moore W, Zhang Y, McMillan R, Wang A, Ali M, et al. Small Molecule Kaempferol Promotes Insulin Sensitivity and Preserved Pancreatic $\beta$-Cell Mass in Middle-Aged Obese Diabetic Mice. 2015;532984.

18. Jessica L, Lang W, Tate DF, Bond DS, Espeland MA, Wing R. Objective estimates of physical activity and sedentary time among young adults. Journal of Obesity. 2017;17:11.

19. McCarthy M, Edwardson CL, Davies MJ, Henson J, Gray L, Khunti K, et al. Change in sedentary time, physical activity, bodyweight, and hba1c in high-risk adults. Med Sci Sports Exerc. 2017;49(6):1120-1125.

20. Bartlett ST, Markmann JF, Johnson P, Korsgren O, Hering BJ, Scharp D, et al. Report from IPITA-TTS Opinion Leaders Meeting on the Future of $\beta$-Cell Replacement. 2016;100(2):S1-44. 
21. Caumo A, Perseghin G, Brunani A, Luzi L. New insights on the simultaneous assessment of insulin sensitivity and beta-cell function with the HOMA2 method. Diabetes Care. 2006;29:2733-2734.

22. Lee S, Bacha F, Hannon T, Kuk JL, Boesch C, Arslanian S. Effects of aerobic versus resistance exercise without caloric restriction on abdominal fat, intrahepatic lipid, and insulin sensitivity in obese adolescent boys: a randomized, controlled Trial. Diabetes; 2012; 61(11):2787-2795.

23. Holmstrup ME, Fairchild TJ, Keslacy S, Weinstock RS, Kanaley JA. Multiple short bouts of exercise over 12 -h period reduce glucose excursions more than an energy-matched single bout of exercise. Metabolism. 2014;63:510-519.

24. Wideman L, Weltman JY, Hartman ML, Veldhuis JD, Weltman A. Growth hormone release during acute and chronic aerobic and resistance exercise. Sports Med. 2012;32:987-1004.

25. Madsen SM, Thorup AC, Overgaard K, Jeppesen PB. High intensity interval training improves glycaemic control and pancreatic $\beta$ cell function of type 2 diabetes patients. PLoS ONE. 2015;10(8).
26. Lee SF, Pei D, Chi MJ, Jeng C. An investigation and comparison of the effectiveness of different exercise programmes in improving glucose metabolism and pancreatic $\beta$-cell function of type 2 diabetes patients. Int J Clin Pract. 2015;69(10):1159-70.

27. Burns N, Finucane FM, Hatunic M, Gilman M, Murphy M, Gasparro D, et al. Early-onset type 2 diabetes in obese white subjects is characterised by a marked defect in beta cell insulin secretion, severe insulin resistance and a lack of response to aerobic exercise training. Diabetologia. 2007;50:1500-1508.

28. Mackenzie R, Maxwell N, Castle P, Elliott B, Brickley G, Watt P. Intermittent exercise with and without hypoxia improves insulin sensitivity in individuals with type 2 diabetes. J Clin Endocrinol Metab. 2012; 97(4):546-E555.

29. Backx K, Mccann A, Wasley D, Dunseath G, Luzio S, Owens D. The effect of a supported exercise programme in patients with newly diagnosed Type 2 diabetes: a pilot study. Journal of Sports Sciences. 2011;29(6):579-586.

30. Dela F, Michael E, Mikines K, Galbo H. Physical training may enhance B -cell function in type 2 diabetes. Am J Physiol Endocrinol Metab. 2004;287:1024-1031. 